\title{
System rządów premierowskich jako nowy typ systemu rządów: casus Wielkiej Brytanii
}

$\mathbf{K}^{\prime}$ lasyczne typologie, z jakimi mamy do czynienia zarówno w prawie konstytucyjnym, jak i politologii, zorientowanej w stronę systemów politycznych, najczęściej nie wyodrębniają szczególnej, wyraźnie osobliwej i zarazem osobnej postaci systemu rządów, jaką są rządy premierowskie. Niemniej zauważa się oryginalność rozwiązania brytyjskiego i jego swoiste wychodzenie poza skalę tradycyjnych systemów rządów ${ }^{1}$. Mimo to konwencjonalne ujęcia odwołują się najczęściej do dwóch podstawowych typów systemów rządów realizowanych w formule rozdzielenia władz, tj. systemu prezydenckiego (który przypomnijmy w sposób wierny i restrykcyjny podchodzi do zasady podziału władz) oraz systemu parlamentarnego (który z kolei zasady podziału nie traktuje w sposób sztywny, interpretując ją, tak w teorii, jak i praktyce dość luźno)². Oczywiście poza nawiasem tej typologii, znajduje się trzeci ,wielki system”, mianowicie system rządów zgromadzenia czy - inaczej mówiąc - system konwentu, który dla odmiany nie przewiduje formuły rozdzielenia władz, co z kolei powoduje, że - po pierwsze - nie mieści się on w klasycznych ujęciach i jest, jak gdyby, na zewnątrz możliwych podziałów i typizacji, oraz - po drugie - że jest dzisiaj wyraźnie endemicznym systemem, w warunkach praktycznych realizowanym jedynie w Szwajcarii, co sprawia, że wszystkie pozostałe jego wcielenia mają dzisiaj walor jedynie archiwalny, a wszelkie dywagacje na ten temat są jedynie abstraktem akademickim ${ }^{3}$.

W efekcie, kiedy mówimy o systemach rządów to mamy na myśli dwa „wielkie systemy”, czyli prezydencjalizm i parlamentaryzm ${ }^{4}$. Oczywiście, przyjąć należy że stanowią one jedynie krańce pewnego kontinuum, a zatem są, mówiąc inaczej, jedynie teoretycznym modelem idealnym, który w rzeczywistości ustrojowo-politycznej jest (bo i musi być) w rozmaity sposób weryfikowany, a czasami również i falsyfikowany. Wspomnieć jednak wypada, że giętkość i swoista plastyczność aranżacji cechuje przede wszystkim system parlamentarny, podczas gdy system prezydencki jest już dużo bardziej odporny na ewentualne modyfikacje i nie poddaje się tak łatwo dostosowaniom do każdorazowych, często bardzo endemicznych, uwarunkowań miejsca i czasu. Stąd notabene jeśli w ogóle mówimy o systemie prezydenckim to mamy na myśli system polityczny USA. Wszędzie indziej, nawet jeśli próbowano go zainstalować to kończyło się to niepowodzeniem, a tworzone ostatecznie systemy były raczej wynaturzoną, zdegenerowaną formą nawiązującą, często zresztą bardzo niekonsekwentnie, do

\footnotetext{
${ }^{1}$ Por. P. Lauvaux, Les grandes démocraties contemporaines, Paris 2004, s. 460 i n.

${ }^{2}$ Por. P. Parini, Régimes politiques contemporains, Paris 1991, s. 131 i n.

${ }^{3}$ Por. J. Szymanek, Modele systemów rzadów (wstęp do analizy porównawczej), „Studia Prawnicze” 2005, nr 3, s. 5 i n.

${ }^{4}$ Szerzej na ten temat zob. D. V. Verney, Parliamentary Government and Presidential Government, w: Parliamentary versus Presidential Government, red. A. Lijphart, Oxford 1992, s. 31 i n.
} 
amerykańskiego pierwowzoru. Jak łatwo się domyśleć, jest tak z powodów oczywistych. Pierwszym jest sztywność koncepcji podziału władz, która powoduje, że w systemie prezydenckim nie ma jakiegoś marginesu swobody jeśli chodzi o ewentualne modyfikowanie podziałem; co powoduje, że można go przenieść albo w wersji kompletnej znanej z USA albo nie, przy czym w tym drugim przypadku odchodzi się, ze zrozumiałych przyczyn, od właściwego systemu prezydenckiego, często deformując go albo nawet całkowicie mu zaprzeczając. Drugim powodem jest endemizm amerykańskiej kultury politycznej i wszystkich tego konsekwencji, włącznie z systemem partyjnym, bez którego prezydencjalizm made in USA nie może najzwyczajniej działać ${ }^{5}$. To w dużym stopniu, jak się zauważa, jest przyczyną wszelkiego rodzaju niepowodzeń w przenoszeniu systemu prezydenckiego do innych państw i rejonów świata 6 .

Zupełnie inaczej jest w przypadku systemu parlamentarnego, który właśnie dlatego że dość swobodnie podchodzi do idei podziału władz może być w rozmaity sposób realizowany w praktyce, czasami bardziej czasami mniej nawiązując do jego teoretycznego wzorca. Dlatego mówi się nawet, że system ten to raczej rodzina systemów, które owszem muszą spełniać jakieś podstawowe, czy też gatunkowe cechy, które w ogóle przesądzają o opcji parlamentarnej, ale poza tym, w szczegółach, są na tyle odmienne, że tworzą prawdziwą paletę rozwiązań czasami mocno oddalonych do właściwego, podręcznikowego modelu parlamentarnego ${ }^{7}$. Z taką m.in. mutacją mamy do czynienia właśnie à propos systemu premierowskiego, dla którego - jak można się domyśleć - system parlamentarny stanowi punkt wyjścia.

Parlamentaryzm, jak wiadomo, narodził się metodą prób i błędów w Anglii, a właściwe rozmiary przybrał w Wielkiej Brytanii, która uznawana jest za prawdziwą kolebkę systemu parlamentarnego, bądź w nieco innej konwencji terminologicznej, parlamentarno-gabinetowego ${ }^{8}$. Nadmieńmy tylko, że jeśli rzeczywiście uznamy, że parlamentaryzm typowym systemem stał się dopiero po jakimś czasie, kiedy zebrano jego poszczególne puzzle, układając je w spójną i koherentną całość, to i brytyjski rodowód parlamentarnej odmiany rządów może być kwestionowany. Owszem, prawdą jest bowiem, że poszczególne elementy tego systemu powstały i rozwijane były na Wyspach, często zresztą dość przypadkowo i chaotycznie, dając dopiero po pewnym czasie pełniejszy obraz, ale prawdąjest też, że jak każdy twór będący produktem długotrwałej, często też kształtującej się powoli i nie zawsze jednoznacznej praktyki musiał być w jakiś sposób uporządkowany i poddany wymogom teorii, a ta - jak wiadomo - powstała w XIX-wiecznej Francji, która słusznie zgłasza pretensje do matkowania systemowi parlamentarnemu, o ile oczywiście system ten potraktujemy serio, właśnie jako system, a nie jedynie zbiór luźno powiązanych ze sobą części ${ }^{9}$.

Nie rozstrzygając sporu o rodowód systemu parlamentarnego, trzeba wskazać, że poza tym iż jest on produktem przede wszystkim bogatej praktyki ustrojowej, jest on też systemem niesłychanie giętkim, elastycznym, co sprawia, że w konkretnych przypadkach możemy mieć do czynienia z różnymi, niekiedy nawet bardzo, wariantami parlamentarnej odmiany rządów. Dlatego m.in. mówi się, że system ten tworzy właściwie rodzinę albo gamę systemów parlamentarnych, że nie ma jednego systemu parlamentarnego, i że występuje on w licznych odmianach i konfiguracjach, mając jedynie pewne cechy, które uznać można za wspólny

\footnotetext{
${ }^{5}$ Por. J.-C. Acquaviva, Droit constitutionnel et institutions politique, Paris 2005, s. 84, 85.

${ }^{6}$ Por. S. Mainwaring, Presidentialism in Latin America, w: Parliamentary versus Presidential..., s. 111 i n.

${ }^{7}$ Por. J.-C.Colliard, Les regimes parlementaires contemporains, Paris 1978, s. 22 i n.

${ }^{8}$ Szerzej na ten temat zob. D. Baranger, Parlementarisme des origines, Paris 1999.

${ }^{9}$ Por. L. Lauvaux, Le parlementarisme, Paris 1997, s. 5 i n.
} 
mianownik wszelkiego rodzaju jego wcieleń, odmian i najrozmaitszych mutacji ${ }^{10}$. Ta wielowariantowość parlamentarnej odmiany rządów jest do pewnego stopnia rzeczą oczywistą, a nawet więcej, gdyż można powiedzieć że niemal definicyjną. Skoro bowiem przyjmujemy, jako punkt wyjścia wszelkich dywagacji na temat systemu parlamentarnego, że jego kanwą jest niepełny albo niekonsekwentny podział władz, to tak jak ten podział może być, i w praktyce jest, niepełny i niekonsekwentny, dopuszczając różnego rodzaju odstępstwa od niego, tak różne mogą być i w rzeczywistości są systemy parlamentarne. Zachowują one parlamentarny kanon, czyli pewną liczę cech koniecznych dla każdego wcielenia parlamentaryzmu, ale w szczegółach różnią się mocno, tworząc de fecto całą paletę systemów parlamentarnych ${ }^{11}$. Wystarczy tylko spojrzeć na tak różne przecież systemy, jak systemy: Portugalii, Belgii, Niemiec, Finlandii, Czech, Węgier, Rumunii, Hiszpanii czy Szwecji, aby zobaczyć, że owszem systemy te mają jakiś wspólny trzon, ale w wielu miejscach diametralnie się od siebie różnią. Mimo to, wszystkie one odwołują się w swoich podstawach do rudymentów systemu parlamentarnego i dlatego właśnie są z definicji systemami parlamentarnymi, choć - jak nie trudno się domyśleć - w praktyce (a często także i w teorii) bardzo różnymi systemami parlamentarnymi.

W politologii od dawien dawna trwa dyskusja na temat cech, które wyznaczają ramy systemu parlamentarnego. W zależności od koncepcji i ujęć badawczych albo wskazuje się na jedną taką cechą, albo na cały ich katalog, który winien być spełniony o ile dany system miałby się mieścić w konwencji rządów parlamentarnych. Jeśli spojrzymy na katalog, to najczęściej w jego ramach wymieniane są takie cechy jak: dualizm władzy wykonawczej; podział zadań w obrębie egzekutywy i scedowanie zadania rządzenia na organ kolegialny, jakim jest gabinet; odpowiedzialność rządu przed parlamentem; czy choćby prawo egzekutywy do przedterminowego zakończenia pełnomocnictw parlamentu ${ }^{12}$. Oczywiście, tworząc bardziej rozwinięte ujęcia do powyższej listy dopisuje się np. kontrasygnatę albo zasadę minimalizacji ustrojowego znaczenia głowy państwa, przy jednoczesnym braku jej politycznej zależności od pozostałych władz, co znakomicie wpisuje się w dawną angielską formułę, zgodnie z którą „król nie może czynić źle”, ale jednocześnie jedynie panuje, a nie rządzi. Widać z tego, że można mnożyć i rozwijać cechy, które muszą być spełnione, aby dany system rządów mógł być zakwalifikowany do zbioru systemów parlamentarnych ${ }^{13}$. Z drugiej jednak strony, nie każda cecha musi być bezwzględnie spełniona, stąd zdarzają się takie elementy szerokiej konstrukcji parlamentaryzmu, które albo są drugo-, bądź nawet trzeciorzędne albo w ogóle odbiera się im miano cechy identyfikującej system parlamentarny. Wystarczy wskazać dwuizbowość parlamentu, która jeszcze jakiś czas temu była uznawana za element konieczny parlamentaryzmu, a dzisiaj straciła już taki status i jest - z punktu widzenia systemu parlamentarnego

\footnotetext{
${ }^{10}$ Por. D. Turpin, Le régime parlementaire, Paris 1997, s. 41 i n.

${ }^{11}$ Por. P. Parini, Régimes politiques..., s. 129 i n.

12 Por. L. Lauvaux, Le parlementarisme..., s. 46 i n.

${ }^{13}$ Katalog taki jest też mocno rozbudowany, a co za tym idzie i niejednolity na gruncie polskiej literatury zob. np.: S. Gebethner, Parlamentarne i prezydenckie systemy rząów (porównawcza analiza politologiczna), „Państwo i Prawo” 1994, nr 7/8, s. 26 i n.; T. Borkowski, System rzq̨ów w nowej Konstytucji, „Państwo i Prawo” 1997, nr 11/12, s. 71 i n.; M. Grzybowski, System rzqdów (Sejm-Prezydent-Rada Ministrów), w: System rzadów Rzeczypospolitej Polskiej. Założenia konstytucyjne a praktyka ustrojowa, red. M. Grzybowski, Warszawa 2006, s. 9 i n.; W. Brodziński, System parlamentarno-gabinetowy. Wykorzystanie modelu rzqdów parlamentarno-gabinetowych w konstytucji Rzeczypospolitej Polskiej, w: Konstytucyjne systemy rzqdów, red. M. Domagała, Warszawa 1997, s. 35 i n.; J. Szymanek, System rzqdów parlamentarnych (ewolucja polityczno-prawnych mechanizmów wspótpracy i równoważenia legislatywy i egzekutywy), w: Systemy rzq̨ów. Dylematy konstytucyjnej regulacji i praktycznej funkcjonalności, red. T. Mołdawa, J. Szymanek, Warszawa 2007, s. 123 i n.
} 
- zupełnie indyferentna. Dlatego uznaje się czasami, że zamiast budowania jakichś rozbudowanych katalogów, obejmujących obligatoryjne cechy systemu parlamentarnego, wystarczy wskazać na jedną, ale za to zasadniczą cechę, bez której żaden system nie może pretendować do miana parlamentarnego. Wydaje się, że podejście takie uzasadnione jest dzisiaj widoczną prima facie wielopostaciowością parlamentaryzmu, która powoduje, że rośnie liczba różnego rodzaju odrębności między państwami respektującymi założenia parlamentaryzmu. Z jednej strony systemem parlamentarnym jest przecież Irlandia, Wielka Brytania, Republika Czeska, Japonia albo Włochy, z drugiej takim samym, tj. parlamentarnym systemem jest współczesna Portugalia, Grecja, Turcja czy Rumunia. Przykład ten potwierdza metodologiczną zasadność uznania jednej, ale za to kluczowej cechy jako ostatecznie przesądzającej o parlamentarnej postaci systemu rządów, bez uwzględniania innych, które nadają odrębny, często endemiczny profil danego systemu. Jeśli wobec tego poprzestaniemy na jednej, konkretnej cesze identyfikującej rządy parlamentarne, to uznaje się, że jest nią polityczna odpowiedzialność rządu przed parlamentem ${ }^{14}$, będąca prostym następstwem swoistego ,prawa rządów parlamentarnych”, zgodnie z którym rząd stanowi emanację większości parlamentarnej, a zatem pozostaje rządem tak długo, jak długo utrzymuje się owa większośćc ${ }^{15}$. Często przyjmuje się, że właśnie zasada politycznej odpowiedzialności rządu przed parlamentem stanowi clou systemu parlamentarnego, pokazując jego podstawową cechę, mianowicie podział władz, ale zarazem ich kooperowanie ze sobą, będące z kolei dowodem na niepełny albo niekonsekwentny podział. Stąd, jak się zaznacza, niezależnie od wszystkich innych elementów, korekt i mutacji jakie występują w szerokiej klasie systemów parlamentarnych, a jakie mogą w konsekwencji te systemy zmienić i zniuansować, kanon parlamentaryzmu utrzymują te wszystkie systemy, które respektują regułę politycznej zależności rządu od parlamentu, bez względu na wachlarz pozostałych cech, konwencjonalnie przypisanych do formacji parlamentarnej ${ }^{16}$.

Uwzględniając powyższe cechy (składniki) koncepcji rządów parlamentarnych, niezależnie od tego czy potraktujemy je łącznie, czy też za taką cechę uznamy wyłącznie zasadę politycznej odpowiedzialności rządu przed izbą, przyjmuje się, że w ramach parlamentarnego systemu rządów zmieścić można bardzo rozmaite systemy, poczynając od ustroju Wielkiej Brytanii, Irlandii, poprzez systemy Belgii, Holandii, Czech czy Węgier, a na Hiszpanii i Niemczech kończąc. Dodać wypada, że również Francja V Republiki, mimo nośnego skądinąd hasła, semiprezydencjalizmu albo ustroju mieszanego, mieści się ostatecznie w formule rządów parlamentarnych, mimo że mechanizmy korekcyjne poszły w jej przypadku wyjątkowo daleko ${ }^{17}$. Niemniej podkreśla się zgodnie, że również we Francji motorem systemu jest reguła zależności rządu od parlamentu ${ }^{18}$. Jest ona na tyle istotna, co doskonale pokazał moment koabitacji ${ }^{19}$, że wszystkie pozostałe cechy konstytucyjnych rozwiązań ulegają ewidentnej parlamentaryzacji, co proponowaną swego czasu formułę ustroju mieszanego czy półprezydenckiego modyfikuje do tego stopnia, iż traci ona swoje metodologiczne i prakseologiczne uzasadnienie. Okazuje się więc, że w gruncie rzeczy bez mała wszystkie europej-

\footnotetext{
${ }^{14}$ Por. J.-C. Colliard, Les regimes parlementaires..., s. 18 i n.

${ }^{15}$ Szerzej na ten temat zob. J. Stembrowicz, Rzad w systemie parlamentarnym, Warszawa 1982, s. $11 \mathrm{i} \mathrm{n}$.

${ }^{16}$ Por. J. A. Cheibub, Presidentialism, Parliamentarism and Democracy, New York 2007, s. 36.

${ }^{17}$ Szerzej na ten temat zob. A. Lijphart, Patterns of Democracy. Government Forms and Performance in Thirty-Sic Countries, New Haven and London 1999, s. 116 i n.

${ }^{18}$ Por. R. Elgie, Political Institutions in Contemporary France, Oxford 2003, s. 95 i n.

${ }^{19}$ Stąd nawet wskazywano, że moment koabitacji stanowił najważniejszą, choć nieformalną zmianę konstytucji V Republiki. La cohabitation fin de la République, red. F. Rouvillois, Paris 2001.
} 
skie systemy polityczne plasują się w rodzinie systemów parlamentarnych ${ }^{20}$. Każdy z nich spełnia wszak najważniejsze kryterium systemu parlamentarnego, mimo, że w szczegółach różni się od pozostałego. Zresztą, także i pozostałe cechy uznawane za kluczowe dla formacji parlamentarnej są najczęściej respektowane (np. dualizm władzy wykonawczej, prawo przedterminowego rozwiązania parlamentu czy kontrasygnata). Potwierdza to generalną uwagę na temat pojemności formuły rządu parlamentarnego, który będąc pewnym ogólnym projektem teoretycznym w warunkach aplikacji praktycznej może przybierać bardzo różne kształty i rozmiary. Z uwagi jednak na spełnienie pewnego koniecznego kwantum cech wspólnych pozostaje, co do zasady, systemem parlamentarnym.

Wspomniana już wielowariantowość systemu parlamentarnego powoduje, że bardzo często w pojemnej klasie systemów parlamentarnych wymienia się kilka podklas. Wspomnieć tu można przykładowo typowy już dziś podział na system parlamentaryzmu dualistycznego, następnie system parlamentaryzmu monistycznego i wreszcie na system parlamentaryzmu zracjonalizowanego ${ }^{21}$. Kryterium to, jak łatwo się domyślać jest głównie kryterium chronologicznym, którego sensem jest przedstawienie ewolucji systemu parlamentarnego i jego wewnętrznych przekształceń, w tym przede wszystkim związków występujących pomiędzy poszczególnymi segmentami składającymi się na system. W innej nieco konwencji terminologicznej można wskazać systemy parlamentarne z dominacją legislatywy, dalej systemy parlamentarne odznaczające się dominacją egzekutywy i wreszcie systemy parlamentarne zakładające równowagę legislatywy i egzekutywy ${ }^{22}$. Z kolei uwzględniając kryterium partyjne wyodrębnia się systemy parlamentarne dwupartyjne, systemy parlamentarne uporządkowanej wielopartyjności i wreszcie systemy parlamentarne wielopartyjności rozchwianej, czy - inaczej mówiąc - nieuporządkowanej ${ }^{23}$. Typologia ta przy tym ujmuje system parlamentarny przez pryzmat jego skuteczności, zwartości i trwałości, w myśl zasady, że system ten jest tym bardziej stabilny i efektywny, im bardziej uporządkowana jest scena partyjna, w jakim on funkcjonuje, stąd czasami zamiast posługiwać się kryterium partyjnym mówi się niekiedy po prostu o systemach parlamentarnych stabilnych, systemach odznaczających się względną stabilnością i systemach chaotycznych, podlegających permanentnym fluktuacjom. W nawiązaniu do kryterium partyjnego systemy parlamentarne można również podzielić na systemy z parlamentaryzmem miękkim $\mathrm{i}$ - a contrario - systemy parlamentaryzmu twardego ${ }^{24}$. Ten pierwszy oznacza stosunkowo słabą rolę partii politycznych, tzn. ich duże rozdrobnienie, z jednej strony, słabą instytucjonalizację wewnętrzną, z drugiej i wreszcie, z trzeciej, wyjątkowo luźną lojalność, a co za tym idzie dyscyplinę partyjną deputowanych. Z kolei parlamentaryzm twardy jest tego wszystkiego odwrotnością, przewidując zasadniczą rolę partii w funkcjonowaniu mechanizmów rządów parlamentarnych. Inną typologią, ale również mającą w tle rolę partii politycznych, uwzględniającą jednak dodatkowo również niesłychanie istotny kontekst kultury politycznej, jest ta, proponująca podział na parlamentaryzm pozytywny i parlamenta-

\footnotetext{
${ }^{20}$ Za system na tyle zmutowany, że niemieszczący się w konwencji rządów parlamentarnych uznawana jest czasami Rosja, traktowana jako postać hiperprezydencjalizmu. Por.: P. Sarnecki, Prezydent Republiki w rozwiazaniach konstytucyjnych państw Europy Środkowej, w: Konstytucja i gwarancje jej przestrzegania. Księga pamiatkowa ku czci prof. Janiny Zakrzewskiej, red. A. Jankiewicz, Warszawa 1996, s. 413 i n.; A. Antoszewski, R. Herbut, Systemy polityczne współczesnej Europy, Warszawa 2006, s. 179 i n.

${ }^{21}$ Por. Por. D. Turpin, Le régime parlementaire..., s. 41 i n.

22 Por. np. A. Siaroff, Comparative Presidencies: The Inedaquecy of the Presidential, Semi-Presidential and Parliamentary Distinctions, „European Journal of Political Research” 2003, t. XLII, nr 3, s. 269 i n.

${ }^{23}$ Por. P. Leroy, Les régimes politiques du monde contemporain, Grenoble 2001, t. I, s. 50, 51.

${ }^{24}$ Por. P. Ardant, Institutions politiques \& droit constitutionnel, Paris 2004, s. 227 i n.
} 
ryzm negatywny ${ }^{25}$. Widać $\mathrm{z}$ tego doskonale, że tym, co w największym stopniu różnicuje wewnętrznie wszystkie systemy parlamentarne, jest stopień zorganizowania bilateralnych relacji między władzą ustawodawczą a wykonawczą (ocenianych bądź to z punktu widzenia teoretycznego, bądź praktycznego), co oznacza, że wszelkie odcienie i kontrasty między systemami parlamentarnymi zasadzają się na tym, na ile stosunki na linii legislatywa - egzekutywa są zrównoważone, na ile zaś odbiegają do zasady równowagi, premiując wyraźnie jedną z Monteskiuszowskich władz, a dalszej konsekwencji rodząc sytuacje konfliktowe, grożące niestabilnością i brakiem efektywności rządzenia ${ }^{26}$.

Po drugiej wojnie światowej, to co nazwano ogólnie racjonalizacją systemu parlamentarnego osiagnęło punkt maksimum ${ }^{27}$. Różnego rodzaju korekty dokonane wewnątrz systemu parlamentarnego poszły tak daleko, że zmieniły diametralnie obraz tradycyjnie pojmowanej formuły rządu parlamentarnego ${ }^{28}$. Doświadczenia niemieckie, potem zaś francuskie (ale przecież nie tylko, by wskazać choćby początkowe rozwiązania portugalskie przyjęte w roku 1976 czy greckie z 1975) jeszcze wyraźniej zróżnicowały paletę systemów parlamentarnych, do tego stopnia, że obok właściwego systemu parlamentarnego zaczęto ustawiać, jako wręcz osobne systemy rządów, system kanclerski, ustanowiony w bońskiej ustawie zasadniczej, i system mieszany à la française ${ }^{29}$. Dzisiaj bardzo często są one uznawane jako odrębne modele rządów, i szeregowane obok właściwego systemu parlamentarnego (dodajmy tutaj, tradycyjnego czy może klasycznego) i systemu prezydenckiego. Argumentem dla takiego stanowiska ma być daleko posunięta modernizacja zarówno systemu kanclerskiego, jak i mieszanego w stosunku do podręcznikowych założeń tradycyjnej koncepcji rządu parlamentarnego. Wskazuje się bowiem, że oba skorygowane (zracjonalizowane) systemy są na tyle nowatorskie i różne od typowego systemu parlamentarnego, że właściwie składają się na osobny model systemu rządów. W przypadku systemu kanclerskiego elementem nowym i gatunkowo odmiennym ma być wyraźna ekspozycja kanclerza, dzięki któremu egzekutywa z dualistycznej przechodzi właściwie na pozycję tralistyczną, co ma rozstrzygać o odmiennym charakterze systemu kanclerskiego ${ }^{30}$. Z kolei w modelu mieszanym, sygnowanym przez V Republikę Francuską, novum na być nieproporcjonalnie wysoka - w porównaniu do każdego wcielenia systemu parlamentarnego - pozycja ustrojowa głowy państwa, nawiązująca do wzorca klasycznego prezydencjalizmu ${ }^{31}$. Stąd właśnie wziął się pomysł, aby system ten uznać za w ,połowie prezydencki”, co jednak niekoniecznie musi odpowiadać prawdzie, gdyż - jak niektórzy zaznaczają - w wielu miejscach jest on bardziej prezydencki aniżeli amerykańska

\footnotetext{
${ }^{25}$ Por. A. Siaroff, Comparative European Party Systems. An Analysis of Parliamentary Elections Since 1945, New York 2000, s. 105

${ }^{26}$ Co zresztą sprawia, że w literaturze spotkać można całą mozaikę propozycji podziału systemów parlamentarnych. Zob. np.: O. Duhamel, Droit constitutionnel et institutions politiques, Paris 2009, s. 181 i n.; D. Chagnollaud, Droit constitutionnel contemporain. Théorie générale. Les régimes étrangers, Paris 2005, t. I, s. 225 i n.

${ }^{27}$ Szerzej na ten temat zob. P. Lauvaux, Parlementarisme rationalisé et stabilité du pouvoir exécutif, Bruxelles 1988, s. 18 i n.

${ }^{28}$ Szerzej na ten temat zob.: A. Łabno, Parlamentaryzm zracjonalizowany. Przyczynek do dyskusji, „Przegląd Prawa i Administracji” 2005 t. LXV, s. 7 i n.; J. Szymanek, Racjonalizacja parlamentarnego systemu rzqdów, „Przegląd Sejmowy" 2007, nr 1, s. 35 i n.

${ }^{29}$ Zwłaszcza ten system rządów postrzegany jest jako autentycznie „,nowy”, gatunkowo odmienny od właściwego systemu parlamentarnego. Por. M. Duverger, Le concept de régime semi-présidentiel, w: Les régimes semi-présidentiels, red. M. Duverger, Paris 1986, s. 7 i n.

${ }^{30}$ Szerzej na ten temat zob. M. Domagała, System kanclerski i możliwości jego zastosowania w nowej konstytucji Rzeczypospolitej Polskiej, w: Konstytucyjne systemy..., s. 113 i n.

${ }^{31}$ Por. B. Branchet, Le fonction présidentielle sous la Ve République, Paris 2008, s. 27 i n.
} 
wersja systemu prezydenckiego ${ }^{32}$. Warto jednak zaznaczyć, że praktyka pokazuje, iż oba wysoce skorygowane systemy, choć cechują się swoistą hiperbolizacją zabiegów racjonalizacyjnych w jednym przypadku odnoszonych do osoby szefa rządu, w drugim zaś do głowy państwa, pozostają mimo wszystko w szeroko pojmowanej koncepcji ustroju parlamentarnego. Ciagle bowiem zakładają takie kluczowe dla niego elementy jak: złożona władza wykonawcza, odpowiedzialność rządu przed parlamentem czy możliwość wcześniejszego rozwiązania zgromadzenia ustawodawczego przez organ władzy wykonawczej. Okazje się zatem, że korekty i przekształcenia, jakie są udziałem poszczególnych systemów parlamentarnych, mimo że w wielu przypadkach rzeczywiście dalece modyfikują rozwiązania klasyczne, nie kwestionują w żadnym punkcie tego wszystkiego, co stanowi podstawę systemu parlamentarnego. W dalszym ciągu więc zachowane są najważniejsze cechy parlamentarnej odmiany rządów, co powoduje, że i niemiecka odmiana systemu kanclerskiego i francuski półprezydencjalizm (a także rozwiązania w jakimś sensie do niego paralelne, np. Republika Weimarska, Finlandia pod rządami konstytucji z 1919 roku czy Portugalia z pierwotnym tekstem konstytucji z 1976 r.) mieszą się w klasie systemów parlamentarnych. Inna sprawa, że klasa ta staje się powoli coraz bardziej pojemna i rozciagliwa, co z kolei - z naturalnych powodów - rodzi zapotrzebowanie na nowe konstrukcje i modele.

$\mathrm{Na}$ tym tle warto się zastanowić czy parlamentarny system brytyjski również, w czasie swojej długotrwałej i przecież nieskończonej ewolucji, nie poszedł przypadkiem tak dalece, że - na swój sposób - wyszedł poza ramy konwencjonalnie ujmowanego systemu parlamentarnego. System ten odznacza się z pewnością cechami endemicznymi, właściwymi tylko dla niego, co sprawia, że choć parlamentaryzm made in Englad był eksportowany do innych systemów politycznych, to jednak nigdzie nie przeniesiono go w sposób wierny, ścisły i dokładny ${ }^{33}$. Z drugiej strony już po tym, jak stał się swoistym produktem eksportowym zaczął podlegać daleko posuniętym przekształceniom w stosunku do tych jego cech, które swego czasu stały się kanwą dla opisu ogólnej formacji parlamentarnej. Na Wyspach ujawniały się bowiem powoli nowe zjawiska i tendencje, obserwowane przede wszystkim w sferze praktyki konstytucyjnej i kultury prawno-politycznej, które zmieniły obraz bilateralnych związków rządu z parlamentem właściwych dla klasycznej postaci parlamentaryzmu. Rodzi się wobec tego pytanie, co dzisiaj w największym stopniu identyfikuje parlamentaryzm brytyjski, co stanowi nową, a przynajmniej nieznaną pozostałym mutacjom parlamentarnej odmiany rządów jakość i, co jest najważniejsze, czy ogół cech nowych bądź też zmodyfikowanych nie prowadzi przypadkiem do ujawnienia się zupełnie nowej, innej od parlamentarnej, a przynajmniej klasycznie parlamentarnej koncepcji systemu rządów?

Na pierwszym miejscu owych cech czy właściwości ustroju parlamentarnego made in England należy wymienić z pewnością system partyjny ${ }^{34}$. Słynna brytyjska dwupartyjność już przeszło 100 lat temu była wszak uznawana za element bodajże w największym stopniu profilujący brytyjską odmianę systemu parlamentarnego, o czym z przekonaniem pisał chociażby Adhémar Esmain, dla którego brytyjska dwupartyjność była wręcz podniesiona do rangi aksjomatu systemu parlamentarnego ${ }^{35}$. Oczywiście, samo pojęcie dwupartyjności jest tutaj pewnym uproszczeniem, swoistym skrótem myślowym, i to nie tylko jeśli uwzględni się wyniki wyborów parlamentarnych z maja 2010 roku. Patrząc przecież na preferencje brytyjskie-

\footnotetext{
${ }^{32}$ Szerzej na ten temat zob. O. Duhamel, Droit constitutionnel..., s. 533 i n.

${ }^{33}$ Por. P. Lauvaux, Les grandes démocraties..., s. 443 i n.

${ }^{34}$ Por. P. Ardant, Institutions politiques..., s. 248 i n.

35 Por. A. Esmein, Prawo konstytucyjne, Warszawa 1921, s. 117 i n.
} 
go elektoratu zawsze obecnych w nim było więcej ugrupowań aniżeli dwie partie dominujące. Dwupartyjność była wobec tego widoczna na poziomie sceny parlamentarnej, ale już niekoniecznie na poziomie systemu partyjnego tout court. Za przykład mogą tu służyć choćby wyniki przedostatnich i ostatnich wyborów przeprowadzonych odpowiednio $\mathrm{w}$ roku 2005 i 2010, kiedy to liberałowie zajęli wyraźnie mocną, trzecią pozycję ${ }^{36}$, co sprawiło, że niektórzy system partyjny wprost zaczęli określać mianem trójpartyjności ${ }^{37}$, patrząc zwłaszcza na realny wynik liberałów, mierzony skalą wyborczego poparcia. Oczywiście, owa trójpartyjność, widoczna w sferze zachowań elektoratu, została w dużym stopniu zmanipulowana w parlamencie. System wyborczy ,,pierwszy na mecie” skutecznie ją bowiem zamortyzował jeśli tylko spojrzeć na rozkład miejsc w Izbie Gmin, która tradycyjnie pozostała zdominowana przez dwie ,wielkie partie" ${ }^{, 38}$. Dzisiaj ta dominacja uległa już, jak wiemy, załamaniu, co notabene doskonale pokazuje, że nawet hermetycznie zamknięte prawo wyborcze, może zmodyfikować kształt sceny partyjnej o ile oczywiście stabilne w swoich tendencjach okażą się zachowania wyborcze elektoratu.

Wspomniana dwupartyjność w istotny sposób przekłada się na pozostałe składniki systemu brytyjskiego ${ }^{39}$ powodując, że na tle innych systemów parlamentarnych, odznacza się on niewątpliwą specyfiką. Wypada tutaj wskazać przede wszystkim, wybór premiera w wyborach powszechnych, czy raczej - jak to kiedyś określił prof. Marek Sobolewski - pod maska wyborów powszechnych, co zdaniem niektórych - w połączeniu $\mathrm{z}$ innymi cechami ustroju brytyjskiego - nadaje temu systemowi cechy wręcz ustroju prezydenckiego ${ }^{40}$. Wspomnieć tu wypada o znanej koncepcji prof. Goeffreya Aldermana, który już jakiś czas temu określił ustrój brytyjski wprost rzadami prezydenckimi ${ }^{41}$. Z pewnością przy tym to, co zbiorczym mianem zostało nazwane rządami prezydenckimi, jest obecnie najbardziej specyficznym rysem ustroju brytyjskiego, na tyle niepowtarzalnym, odmiennym i osobliwym, że nadającym mu status odrębnego od parlamentarnego systemu rządów (a przynajmniej skłaniającym do postawienia takiej tezy) ${ }^{42}$. Proces ten nie jest jednak zupełnie oderwany od znacznie szerszych procesów występujących we współczesnych systemach politycznych, które zostały nazwane „prezydencjalizacją polityki”, a które - mówiąc w skrócie - sprowadzają się do wzrostu roli i znaczenia władzy wykonawczej, a w jej ramach osoby lidera, czemu sprzyja dodatkowo zjawisko personalizacji polityki ${ }^{43}$. Trzeba jednak przyznać, że w ustroju brytyjskim to, co określa się mianem prezydencjalizacji polityki jest szczególnie mocno widoczne. Widać to chociażby w kumulowaniu przez premiera kilku kluczowych z punktu widzenia logiki każdego systemu rządów ról ustrojowych, tj. roli szefa gabinetu, lidera egzekutywy i na końcu lidera partii rządzącej ${ }^{44}$. Ta swoista synteza ról do złudzenia przypomina amerykańskiego

\footnotetext{
${ }^{36}$ Co po wyborach z roku 2010 dało im nawet status partii współrządzącej.

${ }^{37}$ Por. S. Ingle, British Party System: An Introduction, New York 2008, s. 129 i n.

${ }^{38}$ Co zresztą jest ciagle podnoszonym argumentem na rzecz zmiany brytyjskiego systemu wyborczego.

${ }^{39}$ Co widać szczególnie w bilateralnych relacjach rządu z parlamentem. Por. np. R. Brazier, Constitutional Reform: Reshaping the British Political System, Oxford 2008, s. 26 i n.

${ }^{40}$ Por. R. Brazier, Constitutional Practice: The Fundations of British Government, Oxford 1999, s. 73 i n.

${ }^{41}$ Szerzej na ten temat zob. G. Alderman, Some Remarks on the Transition from Parliamentary Democracy to Presidential Government in the United Kingdom, w: Praktyczne i teoretyczne aspekty prawa konstytucyjnego, red. B. Banaszak, M. Bernaczyk, Wrocław 2006, s. 13 i n.

${ }^{42}$ Przy czym zaznacza się, że jego podstawową cechą jest jaskrawa wręcz centralizacja polityki. Szerzej na ten temat zob. G. Allen, The Last Prime Minister, Charlottesville 2002, s. 41 i n.

${ }^{43}$ Por. D. J. Samuels, M. S. Shugart, Presidents, Parties and Prime Ministers. Haw the Separation of Powers Affects party Organization and Behavior, Cambridge 2010, s. 228 i n.

${ }^{44}$ Por. S. Buckley, Prime Minister and Cabinet, Edinburg 2006, s. 95 i n.
} 
prezydenta i rzeczywiście daje mocne podstawy do sformułowania tezy o prezydenckim nachyleniu brytyjskiego systemu rządów ${ }^{45}$.

To, co kryje się pod, wydawałoby się dość nietypowym jak dla Wielkiej Brytanii, hasłem „rządu prezydenckiego" bardzo dobrze więc oddaje specyfikę zmian, której parlamentaryzm brytyjski podlegał, a które ostatnimi czasy zostały w zauważalny sposób zakcelerowane i objęły również i inne pola ${ }^{46}$.

Pierwszą z nich jest wyraźna marginalizacja monarchy, która poszła tak daleko, że w zasadzie z powodzeniem można dzisiaj wyłączyć króla ze struktury władzy wykonawczej ${ }^{47}$. Tym sposobem egzekutywa, odmiennie niż w typowym modelu rządu parlamentarnego, stała się właściwie jednowymiarowa, monistyczna, znowu przypominając pod tym względem system prezydencki $^{48}$. Co ciekawe, nawet uprawnienia ze sfery arbitrażu politycznego, które dzisiaj w systemach parlamentarnych, są zasadniczą domeną aktywności głowy państwa, zostały w dużej części scedowane na brytyjskiego premiera. Jeśli więc, w odniesieniu do brytyjskiego monarchy, można w dalszym ciagu mówić o arbitrażu, to jedynie w jego miękkiej, XIX-wiecznej formule, sprowadzającej się do arbitrażu wartości, arbitrażu przejawiającego się głównie w wyrażaniu pewnych zasad i wartości, które identyfikują państwo ${ }^{49}$. Już jednak arbitraż ujmowany w kategoriach działań politycznych, który poza sferą symboliki zawiera się w określonego rodzaju działaniach inicjujących albo hamujących, jest przemieniony na osobę premiera, co sprawia, że część typowych uprawnień głowy państwa (ze sfery arbitrażu, która często jest postrzegana jako zasadnicze meritum działań głowy państwa $\left.{ }^{50}\right) \mathrm{w}$ realiach brytyjskich jest faktycznie wykonywana przez szefa rządu, co notabene sprzyja tylko przenoszeniu konstrukcji amerykańskiego prezydencjalizmu na grunt brytyjski. Przykładem może być choćby podejmowanie decyzji à propos rozwiązania parlamentu, które przecież odbywa się na Dowding Street, a nie w pałacu Buckingham. Po wyborach z maja 2010 roku, premier Gordon Brown dodał jeszcze jeden istotny, i zarazem mocno symboliczny element, pokazujący niedwuznacznie, że arbitrem w warunkach brytyjskich jest właśnie lider gabinetu a nie monarcha. Otóż, w nietypowej dla Wielkiej Brytanii sytuacji braku jednopartyjnej większości w Izbie Gmin, premier wprost zadeklarował, że czuje się osobiście odpowiedzialny za losy kraju i na stanowisku będzie trwał tak długo, jak długo nie powstanie realna alternatywa stabilnych rządów większościowych. Tym sposobem premier G. Brown wszedł niejako w buty arbitra politycznego, buty, które w założeniach typowych rządów parlamentarnych (i ich różnych odcieni) są zarezerwowane dla głowy państwa ${ }^{51}$. Ten epizod pokazuje jednak ewidentną polityczną ,abdykacje” brytyjskiego monarchy, i postawienie mu jedynie roli, którą swego czasu Gordon Smith nazwał totemem brytyjskiej państwowości ${ }^{52}$. Dzięki temu egzekutywa stała się praktycznie domeną gabinetu i jego lidera, co w istotny sposób dokonało wyłomu

\footnotetext{
${ }^{45}$ Por. D. Watts, British Government and Politics. A Comparative Guide, Edinburgh 2006, s. 112 i n.

${ }^{46}$ Do tego stopnia, że mówi się już dzisiaj wprost o nowym brytyjskim systemie rządów, a nawet więcej, bo o potrzebie napisania nowej, formalnej konstytucji. Por. V. Bogdanor, The New British Constitution, Oxford 2009, s. $215 \mathrm{in}$.

${ }^{47}$ Co jednak dotyczy również i innych głów państw, szczególnie o monarchicznej postaci. Por. R. Rose, D. Kavanagh, The Monarchy in Contemporary Political Culture, „Comparative Politics” 1976, nr 8, s. 560 i n.

${ }^{48}$ Por. R. Brazier, Constitutional Practice..., s. 183 i n.

49 Szerzej na ten temat zob. V. Bogdanor, The Monarchy and the Constitution, Oxford 1995.

${ }^{50}$ Por. J. Szymanek, Arbitraż polityczny głowy państwa, Warszawa 2009, s. 33 i n.

${ }^{51}$ Szerzej na temat tworzenia rządu po wyborach w roku 2010 zob. N. Jones, Campaign 2010: The Making of the Prime Minister, London 2010.

52 Por. G. Smith, Życie polityczne w Europie Zachodniej, Londyn 1992, s. 427.
} 
w koncepcji rządów parlamentarnych ${ }^{53}$, w tym ich w punkcie, w jakim przewiduje się dualizm egzekutywy i wyraźny podział zadań wykonawczych w jej obrębie.

Wyłom ten to jednak nie tylko jednoznaczna dewaluacja osoby króla, ale także - znowu trochę podobnie jak w systemie prezydenckim made in USA - absencja realnych narzędzi egzekwowania politycznej odpowiedzialności gabinetu przed parlamentem. Oczywiście de lege lata Izba Gmin dysponuje właściwymi instrumentami, włącznie z prawem uchwalenia wotum nieufności, ale w praktyce, m.in. na skutek dyscypliny partyjnej połączonej z czytelnym rozkładem miejsc w parlamencie ${ }^{54}$, przestały mieć one jakiekolwiek znaczenie, a rząd praktycznie nie jest zagrożony sankcją w postaci wotum nieufności ${ }^{55}$. Polityka gabinetu może być jedynie tematem rozbudowanej dyskusji parlamentarnej, skąd notabene wzięła się specyficzna i właściwa głównie dla Wielkiej Brytanii funkcja delibercyjna parlamentu, przy jednoczesnej redukcji uprawnień kontrolnych, które w państwach Europy kontynentalnej stanowią - jak wiadomo - rdzeń władztwa legislatywy ${ }^{56}$. Z kolei funkcję kontrolną, której skutkiem jest np. zmiana ekipy rządzącej, przejęły w warunkach brytyjskich partie polityczne, stąd np. zmiany personalne $\mathrm{w}$ gabinecie, $\mathrm{w}$ tym na stanowisku premiera, są funkcją przetasowań partyjnych, a w ich ramach stosowania wewnątrzpartyjnych mechanizmów kontroli i odpowiedzialności. Żeby nie być gołosłownym, przykładem tego typu roszad była nie tak dawna zmiana i zastąpienie premiera T. Blaira przez G. Browna, a jeszcze wcześniej słynny casus z roku 1992, kiedy to $M$. Thatcher utraciła stanowisko premiera, ponieważ cofnięto jej zaufanie wewnątrzpartyjne, powodujące w konsekwencji utratę stanowiska lidera konserwatystów $^{57}$. Po raz kolejny pokazuje to, jak istotne z punktu widzenia deskrypcji brytyjskiego sytemu rządów są uwarunkowania partyjne, które chyba w żadnym innym systemie o orientacji parlamentarnej nie modulują systemu rządów aż z takim skutkiem, żeby de facto zastępować (a właściwie zmieniać) rozwiązania konstytucyjne, zarezerwowane dla bilateralnych związków rządu z parlamentem.

Konkludując stwierdzić trzeba, że współczesny system brytyjski odszedł na tyle daleko od klasycznych czy też typowych cech systemu parlamentarnego, że poszedł w kierunku osobnego typu systemu rządów, mianowicie tzw. rządów premierowskich ${ }^{58}$. Świadczą o tym, po pierwsze, ustrojowo-polityczna eliminacja monarchy i uczynienie władzy wykonawczej praktycznie jednoczłonową, skoncentrowaną w gabinecie firmowanym osobą jego lidera. Po drugie właśnie, szczególne wyeksponowanie osoby premiera, który jest nie tylko wybierany „pod maską wyborów powszechnych” ale również skutecznie monopolizuje prace całego gabinetu, będąc jego swoistym znakiem firmowym, co znakomicie ułatwia zasada solidarnej odpowiedzialności członków gabinetu, w wyjątkowo restrykcyjny i konsekwentny sposób realizowana $\mathrm{w}$ ustroju brytyjskim ${ }^{59}$. Politologiczne procesy prezydencjaliazji i personalizacji polityki tylko te zmiany przyspieszają i czynią jeszcze bardziej widocznymi ${ }^{60}$. W konsekwen-

\footnotetext{
${ }^{53}$ Por. S. Buckley, Prime Minister and Cabinet..., s. 167 i n.

${ }^{54}$ Por. Ch. J. Kam, Party Discipline and Parliamentary Politics, Cambridge 2009, s. 38 i n.

${ }^{55}$ Por. A. H. Birch, British System of Government, New York 1998, 127 i n.

${ }^{56}$ Por. D. Watts, British Government and Politics..., s. 77 i n.

${ }^{57}$ Szerzej na ten temat zob. A. Walkins, A Conservative Coup. The Fall of Margaret Thatcher, London 1992.

${ }^{58}$ Szerzej na ten temat zob. A. Blick, G. Jones, Premiership. The Development, Nature and Power of the British Prime Minister, London 2010.

${ }^{59}$ Por. D. Watts, British Government and Politics..., s. 128.

${ }^{60}$ Por. R. Hefferman, P. Webb, The British Prime Minister: Much More Than ,First Among Equals”, w: The Presidentialization of Politics. A Comparative Study of Modern Democracies, red. T. Poguntke, P. Webb, Oxford 2005, s. 26 i n.
} 
cji, w warunkach brytyjskich to premier kumuluje funkcję rządzenia i w żadnym wypadku nie odpowiada znanej z doby klasycznego parlamentaryzmu zasadzie, iż szef rządu to jedynie „pierwszy wśród równych”. Po trzecie, faktyczna likwidacja uprawnień kontrolnych Izby Gmin wobec gabinetu, co przejawia się głównie w nieobecności wotum nieufności jako narzędzia egzekwowania politycznej odpowiedzialności egzekutywy przed legislatywą, co przecież stanowi clou każdej postaci rządów parlamentarnych ${ }^{61}$. W tym miejscu, o czym często się zapomina, system brytyjski odchodzi bodajże najdalej od typowego systemu parlamentarnego, który bardzo często identyfikowany jest właśnie przez zasadę kontroli politycznej parlamentu w stosunku do rządu. W opiniach choćby R. Capitanta to właśnie funkcja kontrolna scedowana na parlament stanowiła przecież istotę parlamentarnej odmiany rządów, niezależnie od wszelkich retuszy i korekt, jakim system ten był poddawany. Uznać więc wypada, że jeśli tylko uprawnienia kontrolne zostają parlamentowi faktycznie odebrane, to i cała konstrukcja związków rządu z parlamentem ulega zachwianiu na tyle żeby odejść od klasyki systemu parlamentarnego i pójść w kierunku zupełnie od niej odmiennym. Po czwarte wreszcie, w szczególnym, mocno endemicznym systemie partyjnym, który sprawia, że typowe w parlamentarnej odmianie rządów mechanizmy różnego rodzaju związków rządu z parlamentem, są de facto przeniesione na płaszczyznę wewnątrzpartyjną, co do pewnego stopnia tłumaczy również relewantność podziału na rząd i opozycję, który to podział nie jest aż tak czytelny, ani dalekosiężny w przypadku pozostałych systemów parlamentarnych.

Wszystko to sprawia, że system brytyjski można uznać obecnie za na tyle odmienny, że praktycznie nowy, w porównaniu z typowym czy też klasycznym systemem parlamentarnym. Zmiany, jakie miały miejsce w jego obrębie, wyszły bowiem stanowczo poza właściwy albo klasyczny model rządu parlamentarnego, tworząc już nawet nie tyle podklasę, co osobny typ (model) systemu rządów ${ }^{62}$. O ile bowiem w systemie kanclerskim czy nawet francuskim systemie mieszanym, są zachowane generalne cechy podręcznikowej formacji parlamentarnej (np. dualizm władzy wykonawczej albo odpowiedzialność gabinetu przed parlamentem) o tyle w ustroju brytyjskim cechy te zostały podważone, a nawet otwarcie zakwestionowane. Stąd notabene wzięła się paralela z systemem prezydenckim, który pod paroma wglądami rzeczywiście bardziej ilustruje specyfikę rozwiązań brytyjskich, aniżeli tradycyjna matryca systemu parlamentarnego. Bezsprzecznie przy tym głównym elementem spajającym rozwiązania brytyjskie z systemem prezydenckim jest wybór szefa rządu w elekcji bezpośredniej, oraz uczynienie z niego fatycznego lidera egzekutywy, na wzór prezydenta Stanów Zjednoczonych.

Mimo wszystko jednak Wielka Brytania nie może być nazywana ustrojem prezydenckim, jakby to oryginalnie albo zachęcająco nie brzmiało. Jeśli już mówić o prezydenckim nachyleniu czy przechyleniu ustroju brytyjskiego to jedynie w praktyce, a zatem $\mathrm{w}$ politycznym działaniu i ogólnym wizerunku tego systemu ${ }^{63}$. Natomiast absolutnie nie można mówić, że brytyjski system rządów spełnia restrykcyjne kryteria systemu prezydenckiego, a to dlatego, że przecież zupełnie inaczej pojmuje regułę podziału władz, nie nadając jej w żadnym razie separatystycznej wersji, ale adaptując ją w wariancie typowym dla formacji parlamentarnej, tzn. przewidując miękką wersję rozdziału, a w konsekwencji współdziałanie władz, zwłaszcza zaś legislatywy i egzekutywy co, niezależnie od innych cech, w największym stopniu identyfikuje system parlamentarny bez względu na jego partykularne odmienności. Z drugiej

\footnotetext{
${ }^{61}$ Por. I. Holliday, A. Gamble, G. Parry, Fundamentals in British Politics, London 1999, s. 54 i n.

${ }^{62}$ Por. S. Buckley, Prime Minister and Cabinet..., s. 172 i n.

${ }^{63}$ Por. D. Kavanagh, D. Richards, A. Geddes, M. Smith, British Politics, Oxford 2006, s. 196 i n.
} 
jednak strony nie da się systemu wytworzonego w Wielkiej Brytanii całkowicie włożyć w ramy systemu parlamentarnego. Jest on bowiem na tyle endemiczny, na tyle odmienny od tego wszystkiego, co jest uznawane za podręcznikowy przykład parlamentaryzmu, że z pewnością plasuje się już gdzie indziej. Wyrażało to zresztą ukute dużo wcześniej pojęcie party government, które co prawda w swoim sensie ilustrować miało coś zupełnie innego ${ }^{64}$, ale oddaje z pewnością całą odmienność ustroju made in England. Jego zasadniczą osią konstrukcyjną jest wszak ograniczona przestrzeń rywalizacji partyjnej, która w swoich konsekwencjach generuje wszystkie pozostałe cechy systemu brytyjskiego takie jak: uczynienie z premiera lidera partii zarówno w organizacji partyjnej, jak i w parlamencie; faktyczny wybór premiera w wyborach powszechnych; przeniesienie mechanizmu egzekwowania odpowiedzialności parlamentarnej rządu do gremiów wewnątrzpartyjnych; a co za tym idzie, przeorientowanie funkcji legislatywy, polegające zwłaszcza na istotnym ograniczeniu zadań kontrolnych.

Dlatego właśnie kategoria systemu premierowskiego wydaje się być najbardziej adekwatna do uchwycenia jego niewątpliwej specyfiki, a zarazem zaznaczenia punktów odmiennych, których liczba jest na tyle duża, a skala na tyle poważna, że tworzy odmienny od parlamentarnego system rządów ${ }^{65}$. Oczywiście, kwestią dyskusyjną pozostaje to czy system ten jest na tyle odrębny i specyficzny, żeby stanowić zupełnie osobną i odmienną od parlamentaryzmu kategorię systemu rządu. Wydaje się, że mimo daleko posuniętych zmian system ten wciąż zasadza się o pewne rudymenty parlamentaryzmu, co sprawia, że podobnie jak np. system kanclerski, jest on pewną podklasą w szerokiej rodzinie systemów parlamentarnych. W porównaniu jednak z właściwym systemem kanclerskim jego osobliwości, a zarazem odmienności w stosunku do klasycznie ujmowanego systemu parlamentarnego, a jednocześnie zauważalne konotacje z ustrojem prezydenckim są na tyle istotne, że premierowska odmiana rządów z powodzeniem może ubiegać się o status odrębnego, różnego od parlamentarnego systemu rządów.

\section{Summary}

The paper attempts to address the question of whether the prime ministerial system has already emerged as a separate system of governance that differs from classical systems, and whether it can no longer be treated as a certain sub-class in an extensive range of parliamentary systems, but rather as a new type of system in its own right. The principal issue appears to be whether the inherent properties of the prime ministerial variety of governance are sufficiently distinct, significant and different from the parliamentary system, however broadly understood, to give the former a status of a separate governance system from the methodological point of view.

It should be observed that the contemporary British system, which serves as a foundation for our deliberations on the prime ministerial form of governance, has deviated from the classical or typical parliamentary system far enough to actually take the direction of a separate system of governance, namely prime ministerial governance. Firstly, this is evidenced by the removal of the monarch from the political system and establishing executive power as a virtu-

\footnotetext{
${ }^{64}$ Szerzej na ten temat zob. The Nature of Party Government. A Comparative European Perspective, red. J. Blondel, M. Cotta, London 2000.

${ }^{65}$ Por. D. Watts, British Government and Politics..., s. 131, 132.
} 
ally one-element entity concentrated in the Cabinet, and embodied by its leader. Secondly, the figure of Prime Minister is highly emphasized as he is elected 'under the guise of common elections' and he successfully monopolizes the work of his entire Cabinet, becoming a certain 'trademark' of this Cabinet, which is well supported by the principle of joint accountability of all Cabinet members, a principle that is exceptionally strictly and consistently implemented in the British system. The ongoing politological processes that tend to presidentialize and personalize politics are only accelerating these changes and making them even more apparent. The consequence in Britain is that it is the Prime Minister who accrues the power to govern and he by no means falls under the principle of classical parliamentary systems, where the government leader is only "the first among equals". Thirdly, the House of Commons has practically lost its controlling power over the Cabinet, as primarily evidenced in the absence of a vote of no confidence, which would serve as a tool of political accountability of executive power before the legislative, the essence of any form of parliamentary governance. Fourthly, in a highly specific, deeply endemic party system which entails that various links between government and parliament typical of the parliamentary style of democracy are de facto transferred onto the internal party stage, this to an extent also explains the relevance of the division between government and opposition, a division which is neither as clear, nor as far-reaching as in the case of other parliamentary systems.

All this allows us to conclude that the British system is sufficiently different to be deemed new in comparison to a typical or classical parliamentary system. The transformations that have taken place there have gone far beyond the proper, or classical, model of parliamentary governance thus forming not only a sub-class, but a separate type (or model) of governance. 
